\title{
Determinants of Utilization of Agricultural Extension Packages of Selected Arable Crops Among Farmers in Enugu State, Nigeria
}

\author{
Umeh Ogechi J* and Ekwengene Hyacinth $\mathbf{N}$ \\ Department of Rural Sociology and Extension, Michael Okpara University of Agriculture Umudike, Nigeria
}

Submission: December 14, 2016; Published: January 09, 2017

*Corresponding author: Umeh Ogechi J, Department of Rural Sociology and Extension, Michael Okpara University of Agriculture Umudike, Abia, Nigeria, Tel: +2348037420857; Email: Umehogechi2@yahoo.com

\begin{abstract}
The study assessed the determinants of utilization of agricultural extension packages on selected arable crop production among farmers in Enugu state, Nigeria. Specifically, the study examined the socio-economic characteristics of farmers in the study area, ascertained farmers awareness, utilization, perceived factors that enhance utilization and also identified constraints militating against effective utilization of ADP packages in the study area. Multistage sampling techniques were used in selecting 96 respondents for the study. Descriptive statistics was used for data analysis while Tobit regression model was used to test the hypothesis. The results shows that swamp rice production received the highest awareness level while yam/maize/telferia followed by Cassava /maize/Egusi/Telferia intercrop is the most utilized technology by the farmers in the study area. Value addition to farm output was identified as the major reason for utilization of ADP technologies. However, irregular visit and supervision of farmers by extension agents were also identified as major constraint militating against effective utilization of the agricultural extension packages by the ADP. Tobit regression analysis showed that factors such as Level of education $\left(2.592^{* * *}\right)$, Farming experience $\left(3.709^{* * *}\right)$, Farm size $\left(4.608^{* * *}\right)$ and income $\left(2.526^{* *}\right)$ had significant positive relationship with utilization of agricultural extension packages in the study area. It is therefore recommended among others that government should place more emphasis on participatory research. This will ensure active participation of farmers in agricultural research processes and consequently effective utilization of improved technologies by the farmers.
\end{abstract}

Keywords: Determinants of utilization; Agricultural extension packages

\section{Introduction}

In Nigeria, Agricultural Development Programs (ADP) plays the role of extension and input delivery services in the agricultural sector. ADPs liaise with the research institutes for improved technologies in order to effectively deliver services to the farmers. The problems that emanate from agriculture at grass roots level are identified by Extension Personnel and then related to the scientists for plausible solutions. The scientists then work on them to provide solutions in forms of improved technologies. These solutions (improved technologies) are disseminated to the farmers for implementation. Standard agricultural advisory services and the supply of modern inputs such as seed, fertilizer and other associated inputs are important for the promotion of agro-based agriculture among millions of small-scale farmers in Nigeria Ogunsumi \& Abegunde [1].

Although "agriculture remains a key component of Nigeria's economy, and currently contributes about $40.0 \%$ of the GDP and employing about $70.0 \%$ of the active population, the sector, the sector has however, significantly underperformed its potential" (FGN, 2009). This has been clearly manifested in the very high food prices nationwide, food insecurity both at the household and national level and malnutrition especially in children.

Therefore, the most fundamental challenge facing the world today and Nigeria as a country, is food insecurity. The current economic recession being experience in Nigeria has exasperated the situation. It is against this backdrop that the current drive of Nigeria's agricultural policy has been aimed at ensuring sufficient and sustainable agricultural production to feed the over 188 million Nigerians and provide some for export Worldometers [2], Udenwa [3], Nehru [4]. This goal will be achieved by targeting our agricultural research and extension programmes towards the resource-poor farmers, who account for over $80 \%$ of the agricultural production in the country Olawoye [5]. It is 
expected that effective extension strategy will provide adequate capacity building to sufficiently empower farmers/producers to move to the next level of sustainable agricultural production to ameliorate the current food insecurity looming in the country Umeh\& Nwachukwu [6].

Sustainable agricultural development is purely based in the transfer of innovation and technologies. These innovations are regarded as a new ideas, method, practice, or techniques which influence active achievement, sustained increase in farm productivity and income. These innovations may be technical and social innovations usually agricultural innovations fall into the technical innovation. This innovation ranges from simple modified farm practice to complete new technology. According to developing an understanding of extension source and channel use by the client to obtain information is a pre-requisite for efficient educational programme because massages that go unheard or unseen cannot lead to change.

When the rural farmers lack access to knowledge and information that would help them to achieve maximum agricultural yield they not only grope in the dark but are driven to the urban centers in search of formal employment, as the only option for survival mungua [7]. Ways of delivering these massages or information to rural farmers include traditional media such as radio, video, television, films, slides, pictures, drama, dance, folklore, group discussion, meetings, exhibition and demonstration to achieve relative agricultural productivity, increase wealth index of the state and the country in general and provide employment opportunities to the people.

ADPs are the only institutionalized vehicle for agricultural technology transfer in Nigeria since their inception in 1985 Udenwa [3]. The establishment of ADPs is one of the boldest attempts of the federal government to tackle the multifaceted problem of agriculture in Nigeria. The ADP system is designed to improve traditional standard of living of the small-scale farmers, who provide over $90 \%$ of the gross domestic food supplies. In other words, ADPs are there to assist farmers to improve their productivity through active participation in their activities and subsequent utilization of the improved technologies to enhance their production capacity Unamma [8].

The ADPs have shown resilience in the sustenance of agriculture and rural development at the grass root level. Yet in recent times, high food prices occasioned by current national economic recession, rapid population growth among other constraints are rapidly outstripping food production and straining the effectiveness of agricultural production to meet the food needs of the teeming population and also produce the much needed agro-based raw materials for the teeming industries. To what extent are the farmers utilizing these opportunities to better their lot and ensure that there is adequate rural development in their various communities and local government which would lead to effective and efficient agriculture system that will not only supply food and animal protein but also foster the utilization of natural resources in a sustainable manner Against this backdrop, it was considered pertinent to investigate the determinants of utilization of agricultural extension packages of selected arable crops among farmers in Enugu State, Nigeria.

\section{Objectives of the Study}

The broad objective of this study is to assess the utilization of agricultural extension packages among farmers in Enugu State. Specifically, the study:

1. examined the socio-economic characteristics of farmers in the study area,

2. ascertained farmers awareness of agricultural packages transferred through ADP extension services,

3. ascertained utilization of ADP agricultural extension packages by farmers,

4. ascertained perceived factors enhancing utilization of ADP agricultural extension packages and

5. identify constraints militating against effective utilization of ADP agricultural extension packages in the study area.

\section{Hypothesis}

In the course of this study, the following hypothesis was tested:

HO $_{1}$ : the level of rural famers' utilization of agricultural extension packages is not affected by their personal, socioeconomic characteristics.

\section{Methodology \\ Study area}

The study was carried out in Enugu State, Nigeria. Enugu State is in the southeast geopolitical zone of Nigeria and one of the 36 states that make up the Federal Republic of Nigeria. Enugu State has three senatorial zones with 17 Local government Areas (LGAs). It is located on latitude $603000 \mathrm{~N}$ and longitude 70301+OE Federal Republic of Nigeria Official Gazette 2007. The state shares borders with Abia and Imo State to the South, Ebonyi State to East, Benue State to the North East, Kogi State to the Northwest and Anambra State to the West. According to, Enugu State (southeast) lies largely within the rainforest belt of Nigeria which is characterized by high temperatures and humidity with substantial amount of rainfall during the major periods of the year. The mean temperature is between 20 - 300C with rainfall between 0.0098 and 2.18cu (Federal Republic of Nigeria Official Gazette, 2007) It has a total land area of 2,764.9 square meter $\left(7,1611 \mathrm{~cm}^{2}\right)$ Federal Republic of Nigeria Official Gazette 2007) and according to the 2006 census, the state has a population of 3,275, 298 people. Enugu State has well drained soil and good climate, sitting at about 223 meter (732 feet) above the sea level. Economically, the state is predominantly rural and agrarian. The major crops grown in the state are yam, cassava, cocoyam, rice, maize as well as variety of fruits and legumes. The crops 
harvested are processed using various methods like smoking, sun-drying, fermentation, milling (oil extraction), shelling etc. Small proportion of the population is engaged in manufacturing activities and these people are mostly located in Enugu, Oji River and Nsukka (Federal Republic of Nigeria Official Gazette, 2007).

\section{Sampling procedure}

A multistage sampling procedure was adopted for this study. Enugu State covers three (3) agricultural zones namely, Nsuka, Augwu, and Enugu. In the first stage, two agricultural zones were randomly selected for the study. In the second stage, simple random sampling technique was use to select three (2) blocks out of the eight (8) extension blocks in each the zones making it four (4) blocks, while in the third stage, two (2) circles each were randomly selected from each block making it eight (8) circles. Finally, twelve (12) farmers were randomly selected from each of the circle making it ninety six (96) respondents for the study.

\section{Data Collection}

Both primary and secondary sources were explored in data collection. Primary data were collected with the use of structured questionnaire which were administered to the respondents. This was augmented by interview schedule in cases where the respondents are illiterates. Secondary data were also obtained from agricultural extension journals, Newsletters, bulletins, Magazine and oral interview with ENADEP Staffs, and relevant ENADEP records and data of recommended packages/ technologies extended to the farmers in the study area.

\section{Data Analysis}

1. Objectives one, two, three, four and five were analyzed using descriptive statistics such as frequency, percentages and means.

2. Tobit analysis was employed to test the hypothesis.

$$
. Y / Y^{*}=f\left(X_{1}, X_{2}, X_{3}, X_{4}, X_{5}, x_{6}, x_{7}, x_{8}, \mu\right)
$$

The latent variable $\mathrm{Y}=1$ and $\mathrm{Y}^{*}=0$.

$1=$ utilization

$0=$ non - utilization

Where:

$\mathrm{X}_{1}=$ Age (years)

$\mathrm{X}_{2}=\operatorname{Sex}($ male $=1)$

$\mathrm{X}_{3}=$ Marital status (married $=1$ )

$\mathrm{X}_{4}=$ Level of Education in years (years)

$\mathrm{X}_{5}=$ Household size (Number of persons in the household)

$\mathrm{X}_{6}=$ Income (amount in Naira)

$\mathrm{X}_{7}=$ Farming status (full time $=1$ )

$\mathrm{X}_{8}=$ Farming experience (years)

$$
\begin{aligned}
& X_{9}=\text { farm size }(\mathrm{Ha}) \\
& X_{10}=\text { extension contact (yes }=1 \text { ) }
\end{aligned}
$$

\section{Results and Discussion}

Results of the analyzed data are presented and discussed to the objectives of the research work.

\section{Socioeconomic characteristics of farmers}

The following socioeconomic characteristics of farmers were examined. Age, marital status, educational level, household size, income, farming status, farming experience and farm size. They are presented in Table 1.

\begin{tabular}{|c|c|c|c|}
\hline $\begin{array}{l}\text { Socioeconomic } \\
\text { characteristics }\end{array}$ & Frequency & Percentages & Mean \\
\hline \multicolumn{4}{|c|}{ Age } \\
\hline $20-29$ & 4 & 4.16 & \\
\hline $30-39$ & 16 & 16.66 & \\
\hline $40-49$ & 34 & 35.41 & 44.5 \\
\hline $50-59$ & 23 & 23.95 & \\
\hline 60 and above & 19 & 19.79 & \\
\hline \multicolumn{4}{|c|}{ Sex } \\
\hline Male & 64 & 66.6 & \\
\hline Female & 32 & 33.3 & \\
\hline \multicolumn{4}{|c|}{ Marital Status } \\
\hline Single & 8 & 8.33 & \\
\hline Married & 70 & 72.91 & \\
\hline Widow & 15 & 15.62 & \\
\hline Divorced & 1 & 1.04 & \\
\hline \multicolumn{4}{|c|}{ Educational Level } \\
\hline FLSC & 27 & 28.12 & \\
\hline SSCE/WAEC/GCE & 41 & 42.72 & \\
\hline $\mathrm{OND} / \mathrm{NCE}$ & 20 & 20.833 & \\
\hline $\mathrm{HND} / \mathrm{BSC}$ & 8 & 8.33 & \\
\hline M.SC/Ph.D & 0 & 0 & \\
\hline \multicolumn{4}{|c|}{ Household Size } \\
\hline $1-4$ persons & 31 & 32.29 & \\
\hline $5-8$ persons & 61 & 63.54 & \\
\hline $9-12$ persons & 4 & 4.16 & 6.5 \\
\hline \multicolumn{4}{|c|}{ Income $(\mathrm{N})$} \\
\hline
\end{tabular}

Table 1: Distribution of farmers according to their socio economic characteristics. 


\begin{tabular}{|c|c|c|c|}
\hline $5,000-15,000$ & 12 & 12.5 & \\
\hline $15,100-30,000$ & 18 & 18.75 & \\
\hline $30,100-45,000$ & 45 & 46.87 & 37,500 \\
\hline Above 45,100 & 21 & 21.87 & \\
\hline \multicolumn{4}{|c|}{ Occupation } \\
\hline \multicolumn{4}{|l|}{ Farming Status } \\
\hline Full time & 66 & 68.75 & \\
\hline Part time & 30 & 31.25 & \\
\hline \multicolumn{4}{|c|}{ Farming Experience (Years) } \\
\hline $1-10$ & 21 & 21.87 & \\
\hline $11-20$ & 55 & 57.29 & 16 \\
\hline 21 and above & 20 & 20.83 & \\
\hline \multicolumn{4}{|c|}{ Farm Size (HA) } \\
\hline$<1$ & 16 & 16.66 & \\
\hline 2-Jan & 32 & 33.33 & \\
\hline 4-Mar & 42 & 43.75 & 3.5 \\
\hline $5-6$ & 6 & 6.25 & \\
\hline
\end{tabular}

Age

Results from Table 1 indicated that majority (35.41\%) of the sampled farmers fall within the age range of 40 - 49 years the while the least percentage $(4.16 \%)$ falls within the age range of 20 - 29 years. The mean age of farmers in the study area is 44.5 years. The result implies that majority of the farmers in the study area were still energetic and within the active working age Okurut and Betazeka, 2005. This agreed with Umeh et al. [9] who reported that within this working age, farmers are more likely to participate in different research reforms in order to achieve breakthrough that will help the family become financially independent.

\section{Sex}

Table also indicates that majority (66.6\%) of the farmers were male while a $33.3 \%$ were female farmers. This is a clear indication that in the study area male farmers were greater in number than their female counterparts.

\section{Marital status}

The Table further indicates that majority (72.91\%) of farmers were married. this shows that the family will work together in their quest to improve their living standard and this will enhance utilization of innovations and ability to discus and make a wise decision as regards adoption.

\section{Level of education}

Nwachukwu [10] noted that the level of education one has will affect the way one receives a message. In view of this, the educational status of the farmers in the study area was examined. Table 1 show that there is appreciable level of literacy in the study area. Majority (42.72\%) of the farmers had secondary education; followed by $20.83 \%$ of the respondents that had ordinary national diploma. $8.33 \%$ of the respondents had higher national diploma and B.Sc while none of the respondents had M.Sc and Ph.D. Since most of the farmers in the study area are literate, it will be fertile ground for extension work because education helps the farmers to make better, faster and informed decision.

\section{Household size}

Table 1 further show that the mean household size of 8 persons is predominant (63.54\%), while the household's size of 9 - 12 had the least percent $4.16 \%$. Asiabaka [11] also noted that large family size units have a positive relationship with rate of adoption. But finding from this work indicate that household size greater than 6 does well in adoption and utilization of resources for efficient farming. This was corroborated by mostly polygamous families that had larger farm size in the study area and also had surplus after sales.

\section{Farm income}

The Table also indicates that $46.87 \%$ of the farmers make annual return of 30,000 - 45,000 from farming activities. Twenty one $(21.87 \%)$ agreed that they make 45,000 and above, while only $21.87 \%$ agreed that they make 5,000 - 15,000 from farming per year. This result indicates that most of the farmers in the study area live below poverty level since they live below $\$ 1$ per day as stipulated by United Nations.

\section{Farming status}

Furthermore, Table 1 shows that $68.75 \%$ of respondents were full time farmers while $31.25 \%$ were part-time farmers who combine trading, civil service, craft and farming. Van den Ban [12] noted that full time farming which is commercial oriented make active and quick use of research innovations more than part time farmers. Part time farmers are normally subsistence oriented.

\section{Farming experience}

Again, the Table shows that majority $(57.29 \%)$ of farmers had 11 - 20 years farming experience followed by $21.87 \%$ of the farmers that has $1-10$ years farming experience, while only $20.83 \%$ of respondents had 21 years and above farming experience. This indicates that proper utilization of innovation is favored by enough farming experience as experience helps farmers to learn from their past mistakes. Asiabaka [11] also listed farming experience as one of the factors which motivates farmers to accept new ideas and practices. The mean farming experience for farmers in the study area is 16 years.

\section{Farm size}

Lastly, the Table indicates that majority (43.75\% ) of farmers in the study area had 2 - 4 hectares of farm land followed by 
$16.66 \%$ of farmers that had less than 1 hectare, while none of the respondents agreed to have above 6 hectare of farm land in the study area. The result of this study indicates that majority of the interviewed farmers are medium scale holder farmers. Asiabaka (2000) noted that larger farm sizes encourage adoption of innovation and mechanization.

\section{Awareness of agricultural packages transferred to farmer through ADP extension services}

Through ADP extension services in the study area, swamp rice production received the highest (53.13\%) level of awareness followed by cassava/sweet potatoes tuber production with awareness level of $46.87 \%$. Production of fruit juice received the lowest (4.17\%) level of awareness while $95.83 \%$ of the respondents reported that they are not aware of the technology. This trend is an indication of uneven dissemination of technologies by extension agents in the study area yet farmers are in need of information and technologies that will raise their level of income. This is in agreement with findings of Asiabaka (2000) that there are enough packages on the technological shelves and that the missing link is an effective agricultural system to disseminate available technology. Again, farmers in the study area are noted for rice and root/tuber crop production as the staple food; the survey indicated that these two areas had the highest percentage level of awareness.

Table 2: Distribution of respondents according to awareness of agricultural packages transferred to farmers through ADP extension services.

\begin{tabular}{|c|c|c|}
\hline $\begin{array}{l}\text { Crop Combination } \\
\text { (technologies) }\end{array}$ & Aware & Not Aware \\
\hline \multirow{2}{*}{ Yam minisett technology } & 25 & 71 \\
\hline & -26 & -74 \\
\hline \multirow{2}{*}{ Yam/maize/Egusi intercrop } & 29 & 67 \\
\hline & -30.4 & -69.79 \\
\hline \multirow{2}{*}{$\begin{array}{l}\text { Yam/maize/Telferie } \\
\text { intercrop }\end{array}$} & 18 & 78 \\
\hline & -18.75 & -81.25 \\
\hline \multirow{2}{*}{$\begin{array}{l}\text { Cassava /maize/Egusi/ } \\
\text { Telferia intercrop }\end{array}$} & 20 & 76 \\
\hline & -20.83 & -79.16 \\
\hline \multirow{2}{*}{$\begin{array}{l}\text { Dry seasons vegetable } \\
\text { production }\end{array}$} & 20 & 76 \\
\hline & -20.83 & -79.16 \\
\hline \multirow{2}{*}{ Swamp Rice production } & 51 & 45 \\
\hline & -53.13 & -46.88 \\
\hline \multirow{2}{*}{ Upland rice production } & 28 & 68 \\
\hline & -29.17 & -70.83 \\
\hline \multirow{2}{*}{$\begin{array}{l}\text { Processing and utilization of } \\
\text { plantain flour }\end{array}$} & 14 & 82 \\
\hline & -14.59 & -85.41 \\
\hline
\end{tabular}

\begin{tabular}{|c|c|c|}
\hline $\begin{array}{c}\text { Soyabean processing and } \\
\text { utilization (soya milk, } \\
\text { moimoi, akara balls, soya } \\
\text { meal) }\end{array}$ & 21 & 75 \\
\cline { 2 - 3 } & -21.88 & -78.12 \\
\hline Production of fruit juices & 12 & 84 \\
\cline { 2 - 3 } & -4.17 & -95.83 \\
\hline $\begin{array}{c}\text { Cassava/sweet potatoes } \\
\text { tubers production }\end{array}$ & 45 & 51 \\
\cline { 2 - 3 } & -46.87 & -53.13 \\
\hline $\begin{array}{c}\text { Cassava/sweet potatoes } \\
\text { tubers processing and } \\
\text { utilization }\end{array}$ & 29 & 67 \\
\cline { 2 - 3 } & -30.21 & -69.79 \\
\hline
\end{tabular}

Generally, results from Table 2 revealed that apart from swamp rice production, the level of awareness of ADP disseminated technologies was very low. This implies that the EAs could not reach out to most of the farmers to educate them on these technologies. This is bad for adoption as this result agrees with the report of Ekumankama and Nwankwo [13] who stated that access to information about an innovation was the key factor in determining adoption decision and insufficient communication of information to potential end users result to low technology adoption.

\section{Utilization of ADP agricultural extension packages by farmers}

Table 3: Distribution of respondents according to utilization of ADP agricultural extension packages by farmers.

\begin{tabular}{|c|c|c|}
\hline $\begin{array}{l}\text { Crop Combination } \\
\text { (technologies) }\end{array}$ & Utilization & Not utilization \\
\hline \multirow{2}{*}{ Yam minisett technology } & 17 & 79 \\
\hline & -17.71 & -82.29 \\
\hline \multirow{2}{*}{ Yam/maize/Egusi intercrop } & 67 & 29 \\
\hline & -69.79 & -30.21 \\
\hline \multirow{2}{*}{$\begin{array}{l}\text { Yam/maize/Telferie } \\
\text { intercrop }\end{array}$} & 78 & 18 \\
\hline & -81.25 & -18.75 \\
\hline \multirow{2}{*}{$\begin{array}{l}\text { Cassava /maize/Egusi/ } \\
\text { Telferia intercrop }\end{array}$} & 75 & 25 \\
\hline & -78.13 & -21.87 \\
\hline \multirow{2}{*}{$\begin{array}{l}\text { Dry seasons vegetable } \\
\text { production }\end{array}$} & 11 & 85 \\
\hline & -11.46 & -88.54 \\
\hline \multirow{2}{*}{ Swamp Rice production } & 53 & 43 \\
\hline & -55.21 & -44.79 \\
\hline \multirow{2}{*}{ Upland rice production } & 17 & 79 \\
\hline & -17.71 & -82.29 \\
\hline \multirow{2}{*}{$\begin{array}{l}\text { Processing and utilization of } \\
\text { plantain flour }\end{array}$} & 7 & 89 \\
\hline & -7.29 & -92.71 \\
\hline
\end{tabular}




\begin{tabular}{|c|c|c|}
\hline $\begin{array}{c}\text { Soyabean processing and } \\
\text { utilization (soya milk, } \\
\text { moimoi, akara balls, soya } \\
\text { meal) }\end{array}$ & 4 & 92 \\
\cline { 2 - 3 } & -4.17 & -95.83 \\
\hline Production of fruit juices & -4.17 & 92 \\
\cline { 2 - 3 } & 23 & -95.83 \\
\hline $\begin{array}{c}\text { Cassava/sweet potatoes } \\
\text { tubers production }\end{array}$ & -23.96 & 73 \\
\cline { 2 - 3 } & 62 & -76.04 \\
\hline $\begin{array}{c}\text { Cassava/sweet potatoes } \\
\text { tubers processing and } \\
\text { utilization }\end{array}$ & -64.58 & -35.42 \\
\cline { 2 - 3 }
\end{tabular}

Data from Table 3 indicates that out of 12 agricultural extension package (technology) transferred to the farmers by extension agents in the study area, Yam/maize/Telferie intercrop received the highest (81.25\%) level of utilization, followed by Cassava /maize/Egusi/Telferia intercrop (78.13\%), Yam/maize/Egusi intercrop (69.79\%), Cassava/sweet potatoes tubers processing and utilization (64.58\%) and Swamp Rice production (55.21\%). soybean processing / utilization, and production of fruit juices received the lowest (4.17\%) level of utilization each in the study area. This shows that farmers in the study area lack appropriate scientific knowledge about these technologies. Earlier, entries in Table 2 indicated that swamp rice production and cassava/sweet potatoes tuber production received the highest level of awareness while production of fruit juice received the lowest awareness level. Similarly, in Table 3, the same set of technologies also had the highest utilization level. This is an indication that awareness enhances utilization.

This is in agreement with the finding of Odebode [14] who reported that lack of appropriate technological and scientific knowledge application limits agricultural utilization and economic progress. Therefore the ADPs still need to do a lot in the study area to enhance awareness and utilization level of their technologies.

\section{Factors enhancing utilization of ADP agricultural extension packages}

Table 4: Distribution of respondents according to factor enhancing utilization of ADP agricultural extension packages.

\begin{tabular}{|c|c|c|c|}
\hline Variables & Frequency & Percentage & Rank \\
\hline $\begin{array}{c}\text { Easy understanding and } \\
\text { application of technologies }\end{array}$ & 95 & 14.09 & $2^{\text {nd }}$ \\
\hline $\begin{array}{c}\text { Easy accessibility of } \\
\text { technologies }\end{array}$ & 66 & 9.79 & $8^{\text {th }}$ \\
\hline Affordable inputs & 91 & 13.5 & $3^{\text {rd }}$ \\
\hline $\begin{array}{c}\text { Improvement of skills in } \\
\text { farming }\end{array}$ & 78 & 11.57 & $6^{\text {th }}$ \\
\hline Increased farm output & 90 & 13.35 & $4^{\text {th }}$ \\
\hline Value addition to farm output & 96 & 14.24 & $1^{\text {st }}$ \\
\hline Increased standard of living & 69 & 1.023 & $7^{\text {th }}$ \\
\hline Reduced cost of production & 88 & 13.05 & $5^{\text {th }}$ \\
\hline
\end{tabular}

The major factors found to enhance utilization of ADP agricultural extension packages from Table 4 are value addition to farm output (14.24\%), easy understanding and application of technologies $(14.09 \%)$, affordable inputs $(14.50 \%)$, increased farm output $(13.35 \%)$ as well as reduced cost of production (13.05\%).

Most of the respondents agreed that they prefer agricultural extension packages that enhance greater value addition to their farm output. This factor also ensures that they earn higher income and wider array of products from their farm outputs. However, some of the respondents agreed to utilize the packages because of easy accessibility of technologies. This is in agreement with recent findings of Ifenkwe [15] who stated that value additions are steps that alter or add to a product or service. He stated that it is an innovation that is adopted by the farmer to enhance or improve an existing agricultural product and services. According to him, in agricultural practice, altering a product can be the adoption of new agricultural and processing technologies or methods that increase a farmer's capacity and reliability in meeting market demand. He therefore stated that adding value is usually created by focusing on the benefits associated with the agricultural product and services that arises from quality, functionality, forms, places, time and ease of possession of the product. Therefore, the ADPs should consider the utility or benefits of the technologies and promote them along these points to encourage high utilization.

\section{Constraints militating against effective utilization of the agricultural extension packages.}

Table 5: distribution of respondents according to constraints militating against effective utilization of the agricultural extension.

\begin{tabular}{|c|c|c|c|}
\hline Variables & Frequency & Percentage & Rank \\
\hline Land scarcity & 92 & 14.04 & $3^{\text {rd }}$ \\
\hline Scarcity of inputs & 93 & 14.19 & $2^{\text {nd }}$ \\
\hline $\begin{array}{c}\text { Untimely dissemination of } \\
\text { technologies }\end{array}$ & 81 & 12.36 & $6^{\text {th }}$ \\
\hline $\begin{array}{c}\text { Poor understanding of } \\
\text { technology }\end{array}$ & 7 & 1.06 & $9^{\text {th }}$ \\
\hline $\begin{array}{c}\text { Irregular visit and } \\
\text { supervision of farmers by } \\
\text { extension agent }\end{array}$ & 94 & 14.35 & $1^{\text {st }}$ \\
\hline $\begin{array}{c}\text { Untimely availability of } \\
\text { inputs }\end{array}$ & 83 & 12.67 & $5^{\text {th }}$ \\
\hline $\begin{array}{c}\text { Lack of fund } \\
\text { Irregular technology }\end{array}$ & 56 & 13.12 & $4^{\text {th }}$ \\
\hline $\begin{array}{c}\text { No change in yield } \\
\text { Technologies does not agree } \\
\text { with the culture of the } \\
\text { people }\end{array}$ & 2 & 8.39 & $8^{\text {th }}$ \\
\hline
\end{tabular}


Table 5 indicates that the major constraint militating against effective utilization of the agricultural extension packages transferred to the farmers in the study area were irregular visit and supervision of farmers by extension agent (14.35\%), scarcity of input $(14.19 \%)$ and land scarcity $(14.0 \%)$, however $0.30 \%$ of respondent pointed out that some of the technologies not agree with the culture of the people in the study area.

This result is a clear indication that extension services in the study area have not done much in terms of regular visit and supervision in the study area which is the main thrust of the Training and visit (T\&V) system practiced by ADP. Also Jibowu [16] stated that extension agents are poorly motivated in terms of remuneration and provision of transport facilitates to visit the farmers. According to him many extension agent live for away from the farmers thereby minimizing interaction between them and the farmers.

\section{Test of hypothesis}

HO $_{\mathbf{1}}$ : the level of famers' utilization of agricultural extension packages is not affected by their personal, socio-economic characteristics.

Table 6: Tobit regression estimate of the determinants of the level of utilization of agricultural packages transferred through ADP extension services in the study area.

\begin{tabular}{|c|c|c|c|c|}
\hline Variables & Parameters & Estimates & $\begin{array}{l}\text { Std. } \\
\text { Error }\end{array}$ & t-value \\
\hline Constant & $B_{0}$ & 4.458 & 1.206 & $3.696^{* * *}$ \\
\hline Age & $X_{1}$ & -0.013 & -0.008 & -1.639 \\
\hline Sex & $X_{2}$ & -0.094 & -0.251 & -0.376 \\
\hline Marital status & $X_{3}$ & 0.001 & 0.07 & 0.017 \\
\hline $\begin{array}{l}\text { Level of } \\
\text { education }\end{array}$ & $X_{4}$ & 0.056 & 0.035 & $2.592^{* *}$ \\
\hline Household size & $X_{5}$ & 0.071 & 0.066 & 1.075 \\
\hline Income & $X_{6}$ & 0.458 & 0.3 & $2.526^{* *}$ \\
\hline Farming status & $X_{7}$ & 0.001 & 0.07 & 0.017 \\
\hline $\begin{array}{l}\text { Farming } \\
\text { experience }\end{array}$ & $X_{8}$ & 0.01 & 0.014 & $3.709^{* * *}$ \\
\hline Farm size & $X_{9}$ & 0.035 & 0.057 & $4.608^{* * *}$ \\
\hline $\begin{array}{c}\text { Extension } \\
\text { contact }\end{array}$ & $X_{10}$ & 0.057 & 0.036 & $2.593^{* *}$ \\
\hline Chi-Square & & $132.980^{* * *}$ & & \\
\hline Pseudo $\mathrm{R}^{2}$ & & 0.6429 & & \\
\hline Log-likelihood & & 74.867 & & \\
\hline
\end{tabular}

Socio-economic characteristics that may influence the level of famers' utilization of agricultural extension packages were analyzed using Tobit regression estimates presented in Table 6. Results showed that factors such as Level of education $\left(2.592^{* * *}\right)$, Farming experience (3.709***), Farm size (4.608***), income (2.526**) and extension contact (2.593**) had significant positive relationship with utilization of agricultural extension packages in the study area. In other words, an increase or improvement on any of these variables will enhance or boost utilization of agricultural extension packages in the study area ceteris paribus [17-20].

\section{Conclusion}

Agricultural extension services were introduced by the federal government to boost agricultural productivity in Nigeria. Findings from the study show that most of the farmers do not have regular training and visit from extension agents. Most of the farmers are still not aware of some agricultural extension packages transferred by ADP also farmers in the study area still rely on friends and relatives for agricultural information. Major determinants of effective utilization of ADP packages in the study area are Level of education, farming experience, farm size, income and extension contact while major constraint militating against effective utilization of the agricultural extension packages transferred to the farmers in the study area were irregular visit and supervision of farmers by extension agent, scarcity of input and land scarcity, however a fragment of the respondents pointed out that some of the technologies not agree with the culture of the people in the study area. This result is a clear indication that extension services in the study area have not done much in terms of regular visit and supervision in the study area which is the main thrust of the Training and visit $(\mathrm{T} \& \mathrm{~V})$ system practiced by ADP.

\section{Recommendation}

Based on the principal findings of this study the following recommendations were made:

1. Dissemination of research results should be boosted through deploying more extension agents to the area by the government.

2. Agricultural research in Nigeria should emphasize what is known in the literature as farmer participatory research (Schulz, 2000) farmers should actively be involved in the entire research processes. They should first participate in problem identification, then technology development and evaluation. This will ensures that technologies developed will be adopted by the farmers.

\section{References}

1. Ogunsumi LO, Abegunde BO (2011) Evaluation of agricultural extension and delivery services in southwest Nigeria. International Journal of Agri Science 1(4): 581-591.

2. Worldometers (2016) Elaboration of data by United Nations, Department of Economic and Social Affairs, Population Division, World Population Prospects. 
3. Udenwa A (2003) New initiatives in Agricultural Development and Rural Poverty Reduction; A Pragmatic Approach to Good Governance. National Root crop Research Institute, Umudike, Nigeria, p. 9-18.

4. Nehru J (2009) Encyclopædia Britannica. Encyclopædia Britannica 2009 Student and Home Edition. Encyclopædia Britannica Inc., Chicago, USA.

5. Olawoye, Janice E (2009) "Giving a Voice to the Rural Population" in University of Ibadan Inaugural Lectures: Volume II (1998-2002), Ibadan University Publishing House, Nigeria, pp. 583-608.

6. Umeh OJ, Nwachukwu I (2015) Revamping grassroots Agricultural production through the Agricultural Extension Transformation agenda. In: Nwachukwu I (Ed.), comtempolaty issues in extension system and development. pp 2-7.

7. Mungua H (2000) Application of information communication technologies in the agricultural the agricultural sector in Africa: a gender perspective. In: Rethgeber E, Adea EO (Eds.), gender and information revolution in Africa IDRC/ECA, International Development Research Centre, Canada, pp. 123.

8. Unamma RPA (1999) Unpublished Paper "Status of Extension System in South East Agricultural Zone of Nigeria: Way Forward For A University -Based Extension Service.

9. Umeh OJ, Ekumankama O0, Nwachukwu I, Ekwe KC (2015) Comparative performance evaluation of the Agricultural Development Programmes (ADPS) OF Abia and Enugu States, Nigeria. Journal of Agricultural Extension 18 (3).

10. Nwachukwu I (2005) Agricultural Communication: Principles and Practice. lambhouse Publishers, Nigeria.

11. Asiabaka CC (2002) Agricultural Extension: A handbook for development practitioners. Molsytem united services, Omoku, Nigeria, pp. $1-160$.
12. Van den ban AW, Hawkins HS (1996) Agricultural extension. Second edition. Blackwell science Lts, Oxford University Press, UK, pp. 80 217.

13. Ekumankama O, Nwankwo G (2002) a Study of Adoption of Agricultural Innovations in Umuahia Zone, Abia State. Journal of Agricultural Extension 3:17-23.

14. Odebode SO (2008) Appropriate Technology for Cassava processing in Nigeria: User? s point of view. Journal of international women's studies 9(3): 269-279.

15. Ifenkwe GE (2009) Value addition to cassava (Manihot esculanta) for food security: communicating food safety and health implications to farmers. Journal of sustainable Agriculture and Environment. Volume 11(1 \& 2): 4-5.

16. Jibowo AA (2002) Essential of Rural sociology. Gbemisodipo press, Abeaokute, Nigeria, pp. 229- 236.

17. Dimelu MU (2006) Effective linkages in the agricultural innovation transfer sub- system in southeast. Department of Agricultural Extension, University of Nigeria, Nigeria.

18. FGN (2008) "National Food Security Program" Federal ministry of Agriculture and Water Resources, Abuja, Nigeria.

19. FGN (2009) Nigeria: Vision 20:2020. The First National Implementation for NV20:2020 (2010 - 2013). Volume 1: The Vision and Development Priorities (The Economic Transformation Blueprint), National Planning Commission, Abuja.

20. Nwachukwu I (2008) Planning and Evaluation of Agricultural and Rural Development Projects. lambhouse Publishers, Umuahia, Nigeria.

\begin{tabular}{l} 
Your next submission with Juniper Publishers \\
will reach you the below assets \\
- Quality Editorial service \\
- Swift Peer Review \\
- Reprints availability \\
- E-prints Service \\
- Manuscript Podcast for convenient understanding \\
- Global attainment for your research \\
- Manuscript accessibility in different formats \\
( Pdf, E-pub, Full Text, audio) \\
- Unceasing customer service \\
Track the below URL for one-step submission \\
https://juniperpublishers.com/online-submission.php \\
\hline
\end{tabular}

